\title{
Serbuk Daun Kelor Menurunkan Derajat Perlemakan Hati dan Ekspresi Interleukin-6 Hati Tikus dengan Kurang Energi Protein
}

\section{Moringa oleifera Leaf Powder Decrease Fatty Liver Degree and Liver Interleukin-6 Expression of Rat with Protein Energy Malnutrition}

\author{
Agustiana Dwi IV', Tinny Endang $H^{2}$, Hidayat Sujuti ${ }^{3}$ \\ ${ }^{1}$ Laboratorium Gizi Fakultas Kedokteran Universitas Brawijaya Malang \\ ${ }^{2}$ Laboratorium Patologi Klinik Fakultas Kedokteran Universitas Brawijaya Malang \\ ${ }^{3}$ Laboratorium Biokimia-Biomolekuler Fakultas Kedokteran Universitas Brawijaya Malang
}

\begin{abstract}
ABSTRAK
Kurang energi protein (KEP) merupakan salah satu bentuk malnutrisi karena rendahnya asupan gizi. Pada KEP gambaran histopatologi liver akan menunjukkan perlemakan hati yang bereaksi dengan radikal peroksidasi membentuk lipid peroksidasi yang meningkatkan ekspresi Interleukin6 (IL-6). Penelitian ini dilakukan untuk membuktikan bahwa konsumsi serbuk daun kelor dapat menurunkan derajat perlemakan hati dan ekpresi IL-6 pada KEP. Penelitian dilakukan dengan desain post test only control group, pada enam kelompok (diet normal, diet rendah protein, diet rendah protein dengan empat perlakuan dosis kelor yaitu $180 \mathrm{mg}, 360 \mathrm{mg}, 720 \mathrm{mg}, 1440 \mathrm{mg}$. Diet rendah protein diberikan dalam 2 bulan kemudian dilanjutkan dengan 1 bulan diet normal yang ditambahkan serbuk daun kelor. Hasil uji One Way ANOVA menunjukkan bahwa pemberian serbuk daun kelor pada semua dosis dapat menurunkan derajat perlemakan hati dan ekspresi IL-6. Pada dosis 720 mg/hari, derajat perlemakan hati dan ekspresi IL-6 menurun hingga sama dengan kelompok normal. Dapat disimpulkan bahwa pemberian serbuk daun kelor pada KEP dapat menurunkan derajat perlemakan hati dan ekspresi IL-6.
\end{abstract}

Kata Kunci: Ekspresi IL-6, kurang energi protein, perlemakan hati, serbuk daun kelor

\begin{abstract}
Protein Energy Malnutrition (PEM) is one of malnutrition type that resulted from underfed energy and protein. Liver histopathologic of PEM shows a fatty liver. Double unsaturated fatty acids in liver will interact with peroxidation radicals to form lipid peroxidation that can increase the expression of Interleukin-6 (IL-6) a proinflammation cytokine. The purpose of this study was to prove that kelor leaf powder (Moringa oleifera) can decrease fatty liver and IL-6 expression of rat's liver in PEM condition. The study design used post test only control group. This research was conducted using six groups there were $K(-)$ or normal diet group, $K(+)$ or non protein diet group for 2 months followed by normal diet for 1 month, P1, P2, $P 3$, and P4 (non protein diet for 2 months following by normal diet and kelor powder $180 \mathrm{mg}, 360 \mathrm{mg}, 720 \mathrm{mg}, 1440 \mathrm{mg}$ respectively). The data were analysed using One Way ANOVA followed by Post Hoc Duncan. The result showed that all dose of kelor leaf powder can decrease IL-6 expression as well as fatty liver degree. At dose $720 \mathrm{mg} /$ day the degree of fatty liver and the expression of IL-6 was very low and were not significantly different with normal group. It could be concluded that kelor leaf powder can decline IL-6 by reducing the degree of fatty liver at certain dose.
\end{abstract}

Keywords: Fatty Liver, Interleukin-6, Moringa oleifera leaf powder, Protein Energy Malnutrition

Jurnal Kedokteran Brawijaya, Vol. 26, No. 3, Februari 2011; Korespondensi: Agustiana Dwi IV. Laboratorium Gizi, Fakultas Kedokteran Universitas Brawijaya, Jl. Veteran Malang Tel. (0341)569117Email:venty_suhendri@yahoo.com 


\section{PENDAHULUAN}

Lebih dari sepertiga anak-anak di dunia menderita kurang energi protein (KEP) dengan indikator wasting, stunting, maupun berat badan rendah (1). Pada tahun 2003 prevalensi gizi kurang di Indonesia sebesar 27,5\% dan meningkat menjadi $28 \%$ pada tahun 2006 . Hal tersebut diiringi dengan meningkatnya gizi buruk dari 8,2\% pada tahun 2003 menjadi 8,5\% pada tahun 2006 (2,3). Daerah Nusa Tenggara Timur mengalami Kejadian Luar Biasa (KLB) gizi buruk pada tahun 2004-2006. Pada tahun 2008 terdapat 3,023 balita yang terindikasi gizi buruk (4).

Beberapa penelitian secara in vivo menyatakan bahwa jika satu atau lebih asam amino tidak terpenuhi akan menyebabkan gangguan pertumbuhan (5). Rendahnya intake asam amino dibandingkan kebutuhan untuk sintesis dan metabolisme dalam tubuh mengakibatkan menurunnya sintesis albumin (6). Turunnya sintesis apoprotein yang merupakan komponen pembentuk lipoprotein juga diakibatkan rendahnya asam amino dalam tubuh. Salah satu lipoprotein adalah Very Low Density Lipoprotein (VLDL) yang terdiri dari apoprotein B100 dan apoprotein $C$ yang berfungsi mengangkut trigliserida dan kolesterol dari hati ke jaringan. Hal ini mengakibatkan akumulasi lemak di hati yang berlebihan yang dikenal dengan perlemakan hati. Pada KEP terbukti terjadi perlemakan hati (7).

Interleukin-6 merupakan sitokin proinflamasi yang dihasilkan dalam respon terhadap trauma pada jaringan oleh sel darah putih, makrofag dan sel endotelial (8). Pada keadaan KEP, sitokin ini meningkat secara signifikan dibandingkan dengan kelompok berstatus gizi normal. Interleukin-6 berperan sebagai mediator proinflamasi dan meningkat pada kondisi Non Alkoholic Fatty Liver Diseases (NAFLD) baik pada serum maupun pada biopsi hati (9).

Radikal bebas yang meningkat pada KEP menyebabkan progesivitas kerusakan hati yang mengakibatkan aktivasi Reactive Oxygen Species (ROS) (10). Meningkatnya radikal bebas dan produksi sitokin proinflamasi pada perlemakan hati menyebabkan steatosis. Inflamasi yang berkepanjangan akan menyebabkan kerusakan jaringan (11).

Kelor (Moringa oleifera) banyak dijumpai di daerah tropis maupun sub tropis. Tanaman tersebut telah memperbaiki kondisi malnutrisi dengan ditambahkan pada diet harian anak. Kelor menjadi sumber vitamin A dan zat besi terbaik dibandingkan beberapa tanaman leguminoceae. Kelor mengandung 40 nutrien essensial. Tanaman ini berperan sebagai anti bakteri dan antioksidan kuat. Akivitas antioksidan dari daun kelor secara langsung berkaitan dengan kandungan asam lemak diantaranya adalah polifenol (12). Kelor varietas lokal Nusa Tenggara Timur (NTT) mempunyai kualitas tinggi dan mudah dibudidayakan karena tahan terhadap hama dan daerah panas. Tanaman ini mengandung zat gizi mikro dan makro yang cukup tinggi (13). Penelitian eksperimental laboratorium ini dilakukan untuk mengetahui dan membuktikan efek serbuk daun kelor varietas NTT terhadap perlemakan hati dan ekspresi IL-6 pada hati tikus KEP. Penelitian ini diharapkan menjadi bagian dari upaya pencarian solusi untuk pengentasan rawan pangan dan gizi dengan kearifan lokal.

\section{METODE}

Penelitian ini bersifat eksperimental laboratorik in vivo dengan desain post test only with control group. Hewan coba yang digunakan adalah tikus galur wistar, jenis kelamin jantan sehat (bulu bersih, gerakan aktif, dan mata jernih), umur \pm 2 bulan ( 6-8 minggu), berat badan $150-200$ gram. Hewan coba dibagi dalam 6 kelompok dengan masing-masing 4 tikus. Hasil uji One Way ANOVA menunjukkan tidak ada perbedaan signifikan berat badan awal $(p=0,317)$ dan berat badan pada masa aklimatisasi $(p=0,696)$ antar kelompok.

Kelompok 1 (K-) adalah tikus yang diberi diet normal. Kelompok $2(\mathrm{~K}+)$ adalah tikus yang diberi diet non protein selama 2 bulan dilanjutkan diet normal selama 1 bulan. Kelompok 3 (P1) adalah tikus yang diberi diet non protein selama 2 bulan dilanjutkan diet normal dan serbuk daun kelor dengan dosis $180 \mathrm{mg} /$ hari selama 1 bulan. Kelompok 4 (P2) adalah tikus yang diberi diet non protein 2 bulan dilanjutkan diet normal dan serbuk daun kelor dengan dosis 360 mg/hari selama 1 bulan. Kelompok 5 (P3) adalah tikus yang diberi diet non protein 2 bulan dilanjutkan diet normal dan serbuk daun kelor dengan dosis $720 \mathrm{mg} /$ hari selama 1 bulan. Kelompok 6 (P4) adalah tikus yang diberi diet non protein 2 bulan dilanjutkan diet normal dan serbuk daun kelor dengan dosis $1440 \mathrm{mg} /$ hari selama 1 bulan. Selanjutnya tikus dibedah dan diambil hatinya untuk pengukuran derajat perlemakan hati dan ekspresi IL-6 hati (14) secara imunohistokimia.

Pakan tikus dengan diet normal mengandung 102,8 kalori/hari dan pakan tikus dengan diet KEP mengandung 71,18 kalori/hari. Diet normal mengandung protein sebesar 4,9 gram sedangkan diet KEP tidak mengandung protein. Pemberian diet normal pada tikus disesuaikan kebutuhan normal tikus yaitu 102,8 kalori/hari untuk 30 gram diet normal dengan komposisi karbohidrat 18,8 gram, lemak 0,89 gram dan protein 4,9 gram. Diet KEP diberikan sebanyak 20 gram dengan komposisi karbohidrat 13,96 gram lemak 1,62 gram dan protein 0 gram.

Perlakuan dengan diet KEP telah menunjukkan gambaran sesuai dengan yang diharapkan yaitu penurunan asupan pakan, berat badan dan gambaran klinis KEP pada kelompok kontrol positif dan perlakuan. Uji One Way ANOVA menunjukkan perbedaan asupan pakan signifikan antara kelompok diet normal dan diet $\operatorname{KEP}(p<0,001)$. Hasil uji One Way ANOVA juga menunjukkan perbedaan signifikan pertumbuhan berat badan antar kelompok. Kelompok perlakuan dengan diet KEP mengalami penurunan berat badan yang signifikan dibandingkan diet normal $(p<0,001)$.

Pengukuran IL-6 dan perlemakan hati dimulai dengan mempersiapkan slide organ untuk dideparafinasi dan rehidrasi dengan cara merendam slide organ dalam xylol sebanyak 2 kali dilanjutkan alkohol secara bertingkat (100\%, 90\%, 80\%, 70\%, 30\%) dan aquabides secara berurutan. Slide kemudian dicuci dengan Phetal Bovine Serum (PBS) pH 7,4 sebanyak 3 kali selama 5 menit. Proses selanjutnya adalah permeabilisasi sel dengan mencuci spesimen dengan PBS kemudian sel dinkubasi pada $3 \%$ $\mathrm{H}_{2} \mathrm{O}_{2}$ dalam PBS selama 10 menit pada suhu ruang kemudian dicuci 3 kali dengan PBS. Bloking sel dilakukan dengan menginkubasi sel $1 \%$ pada Bovine Serum Albumin (BSA) selama 1 jam pada suhu ruang kemudian dicuci dengan PBS 3 kali selama 5 menit. Selanjutnya sel diinkubasi pada antibodi primer yang diencerkan dalam BSA selama 5 menit sebanyak 3 kali. Setelah itu sel 
diinkubasi dengan antibodi sekunder yang telah diencerkan dalam PBS selama 1 jam pada suhu ruang. Sel pada slide organ dicuci dengan PBS sebanyak 3 kali selama 5 menit kemudian ditetesi dengan Strept Avidin Horse Radish Peroxidase (SA-HRP) 1:1500 dalam PBS selama 40 menit. Sel pada slide organ kemudian dicuci dengan PBS sebanyak 3 kali selama 5 menit dan ditetesi dengan Diaminobenzidine (DAB) selama 10 menit. Sel dicuci dengan air kran kemudian dicuci lagi dengan aquades selama 10 menit pada suhu ruang. Proses diakhiri dengan mounting menggunakan entelan dan diamati dibawah mikroskop $(15,16)$. Data dianalisis melalui beberapa tahap pengujian, yaitu: uji homogenitas varians, uji One Way ANOVA, uji post hoc test Duncan.

\section{HASIL}

\section{Derajat Perlemakan}

Secara histopatologis (Gambar 1) kelompok P3 menunjukkan derajat perlemakan hati yang paling rendah dan tidak terdapat perbedaan dengan kelompok kontrol (K-). Gambaran perlemakan yang menonjol ditemukan pada kelompok diet KEP tanpa perlakuan daun kelor $(\mathrm{K}+)$ yang semakin berkurang pada kelompok P1 dan P2 dengan pemberian daun kelor, $180 \mathrm{mg}$ dan $360 \mathrm{mg}$.

Derajat perlemakan hati merupakan persentase jumlah sel lemak pada jaringan hati tikus. Analisis terhadap derajat perlemakan (Gambar 2) yang dilakukan menggunakan uji One Way ANOVA menunjukkan bahwa ada perbedaan rata-rata derajat perlemakan hati yang signifikan pada keenam kelompok perlakuan $(p<0,001)$. Uji post hoc test Duncan menunjukkan terdapat penurunan derajat perlemakan hati dengan pemberian ekstrak daun kelor pada semua dosis. Derajat perlemakan hati pada kelompok $\mathrm{K}(+)$ berbeda bermakna dengan semua kelompok perlakuan.

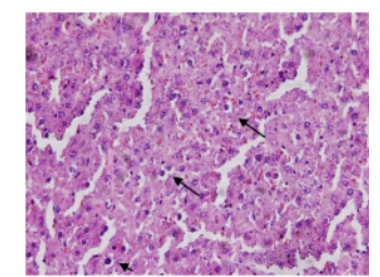

$\mathrm{K}(-)$

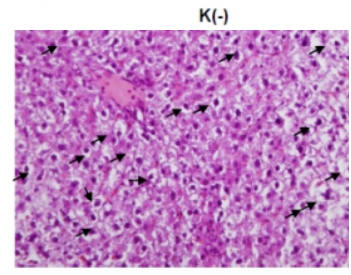

P1

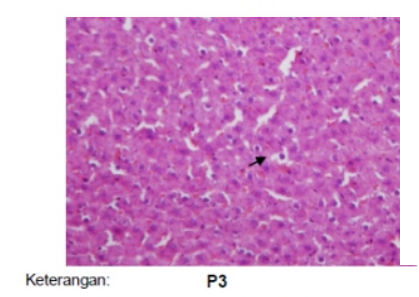

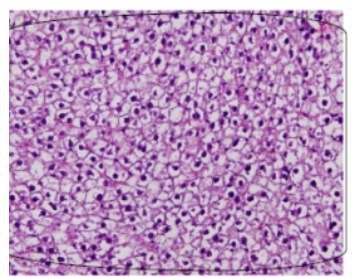

$\mathrm{K}(+)$

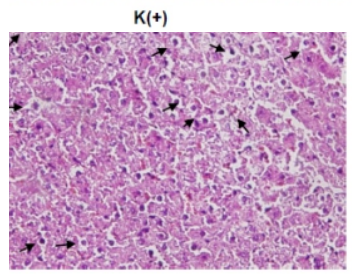

P2

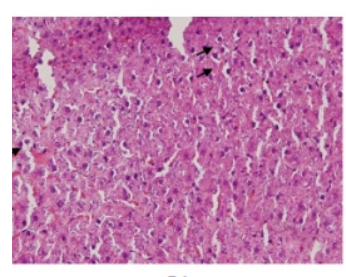

Gambar 1. Gambaran derajat perlemakan hati pada tiap kelompok.

Keterangan: Pengecatan hematoxylen eosin dengan menggunakan mikroskop cahaya olympus DP 71 perbesaran 400X.

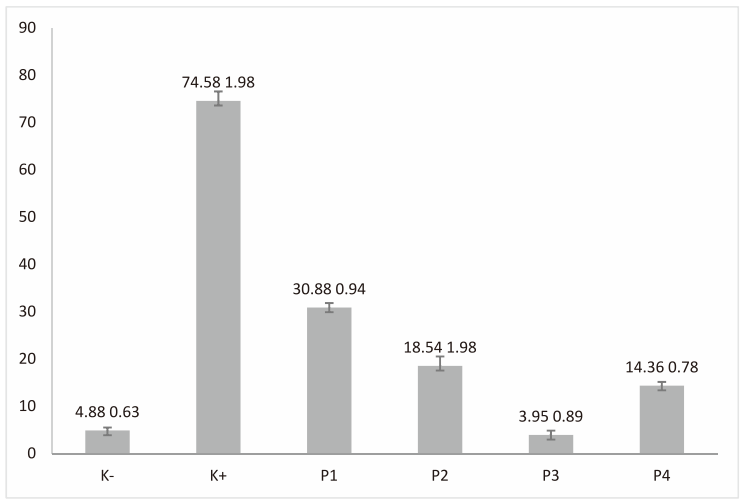

Gambar 2. Derajat perlemakan hati

Keterangan:

$\mathrm{K}(-)$ : Kelompok kontrol negatif diberikan diet normal

$\mathrm{K}(+)$ : Kelompok kontrol positif diberikan diet non protein dilanjutkan diet normal tanpa serbuk daun kelor

P1 : Kelompok perlakuan 1 diberikan diet non protein dilanjutkan diet normal + 180 mg serbuk daun kelor

P2 : Kelompok perlakuan 2 diberikan diet non protein dilanjutkan diet normal $+360 \mathrm{mg}$ serbuk daun kelor

P3 : Kelompok perlakuan 3 diberikan diet non protein dilanjutkan diet normal + $720 \mathrm{mg}$ serbuk daun kelor

P4 : Kelompok perlakuan 4 diberikan diet non protein dilanjutkan diet normal + $1440 \mathrm{mg}$ serbuk daun kelor

Kondisi KEP akibat diet non protein mengakibatkan meningkatnya ekspresi IL-6. Pemberian diet normal dan serbuk daun kelor menurunkan ekspresi IL-6 (Gambar 3). Kelompok P3 (daun kelor 720 mg) menunjukkan ekspresi IL-6 yang paling rendah dan tidak terdapat perbedaan dengan kelompok kontrol negatif.

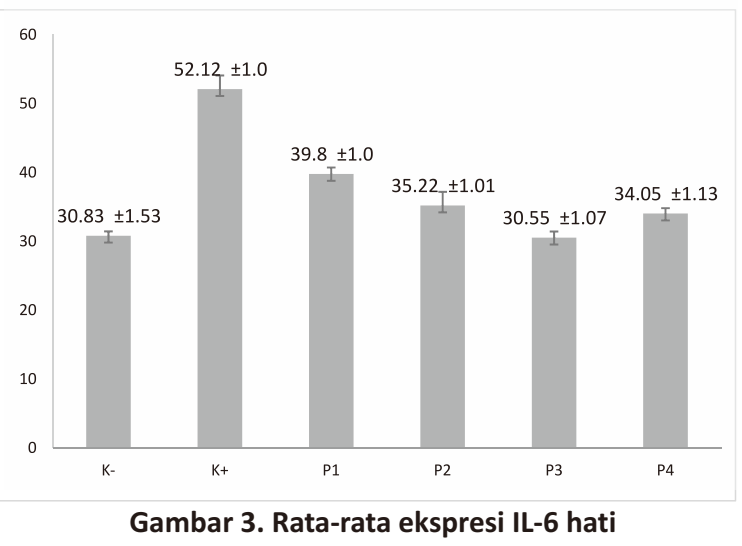

Keterangan:

$\mathrm{K}(-)$ : Kelompok kontrol negatif diberikan diet normal

$\mathrm{K}(+)$ : Kelompok kontrol positif diberikan diet non protein dilanjutkan diet normal tanpa serbuk daun kelor

P1 : Kelompok perlakuan 1 diberikan diet non protein dilanjutkan diet normal +180 mg serbuk daun kelor

P2 : Kelompok perlakuan 2 diberikan diet non protein dilanjutkan diet normal + 360 mg serbuk daun kelor

P3 : Kelompok perlakuan 3 diberikan diet non protein dilanjutkan diet normal + 720 mg serbuk daun kelor

P4 : Kelompok perlakuan 4 diberikan diet non protein dilanjutkan diet normal + $1440 \mathrm{mg}$ serbuk daun kelor

Uji statistik One Way ANOVA menunjukkan terdapat perbedaan rata-rata ekspresi IL-6 yang signifikan antar kelompok $(p<0,001)$. Uji post hoc test Duncan menunjukkan terdapat penurunan ekspresi IL-6 dengan 
pemberian ekstrak daun kelor pada semua dosis.

Gambar 4 menunjukkan secara histopatologis, didapatkan gambaran jaringan hati dengan warna coklat yang menunjukkan ekspresi IL-6. Ekspresi yang sangat menonjol ditunjukkan oleh kelompok kontrol positif.

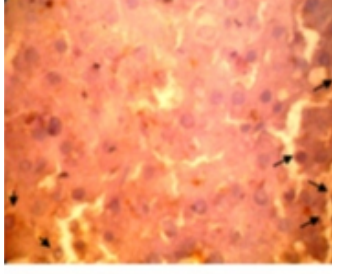

k(-)

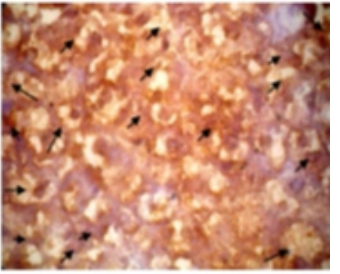

P1

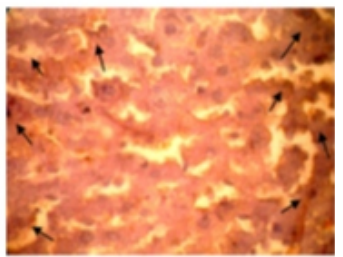

P3

Gambar 4. Gambaran ekspresi IL-6 hati pada tiap kelompok.

Keterangan: Sel yang mengekspresikan IL-6, pengecatan hematoxylen eosin dengan menggunakan mikroskop cahaya olympus DP 71 dengan perbesaran 400X yang ditandai warna coklat.

\section{DISKUSI}

Proses penelitian diawali dengan pengkondisian KEP dan pemberian asupan tambahan daun kelor yang ternyata memberikan pengaruh pada asupan pakan. Oleh karena itu pada pembahasan disamping disajikan dampak perlemakan hati dan ekspresi IL-6 juga dikaji dampak pemberian daun kelor pada asupan pakan.

\section{Efek Daun Kelor pada Asupan Pakan}

Rata-rata asupan pakan setelah diberikan diet normal dengan serbuk daun kelor cenderung mengalami penurunan. Asupan pakan antar kelompok perlakuan dengan penambahan daun kelor (P1, P2, P3, dan P4) tidak menunjukkan perbedaan yang signifikan. Jumlah asupan kelompok tersebut menurun signifikan bila dibanding kelompok $\mathrm{K}(+)$ yang tidak mendapatkan penambahan serbuk daun kelor. Faktor pakan yang mempengaruhi penurunan jumlah asupan meliputi warna pakan, tekstur dan aroma pakan. Kelompok $\mathrm{K}(+)$ sebelumnya juga mengalami KEP namun asupannya justru meningkat setelah diberi diet normal tanpa penambahan daun kelor.

Penambahan serbuk daun kelor pada diet normal diduga mempengaruhi selera makan sebab menimbulkan warna dan aroma berbeda terhadap diet normal. Semakin banyak dosis serbuk daun kelor yang diberikan ke dalam diet normal maka semakin berwarna kehijauan dan beroma seperti daun teh hijau. Hal ini dibuktikan dengan jumlah asupan tertinggi adalah pada kelompok P1 (diet normal dengan penambahan serbuk daun kelor dosis terkecil, $180 \mathrm{mg}$ ) sedangkan jumlah asupan terendah adalah pada kelompok P4 (diet normal dengan penambahan serbuk daun kelor dosis tertinggi, $1440 \mathrm{mg}$ ).

Salah satu penyebab kurang gizi pada anak adalah kurangnya asupan makanan. Hal ini terjadi karena tidak ada keinginan anak untuk makan. Faktor tersebut dipengaruhi oleh tingkat kesenangan pada jenis makanan oleh anak. Tingkat kesenangan pada makanan dipengaruhi beberapa faktor yang ada pada makanan. Faktor tersebut antara lain: bentuk, warna, aroma, tekstur dan rasa (17).

\section{Efek Daun Kelor pada Derajat Perlemakan Hati}

Penelitian ini membuktikan pemberian serbuk daun kelor (Moringa oleifera) varietas Nusa Tenggara Timur dapat menurunkan derajat perlemakan hati dan ekspresi IL-6 hati tikus putih (Rattus novergicus strain wistar) KEP. Hasil menunjukkan kelompok dengan diet KEP menunjukkan perlemakan hati yang paling tinggi diikuti penurunan pada kelompok perlakuan diet normal dan serbuk daun kelor. Derajat perlemakan hati yang paling rendah dan mendekati normal ada pada kelompok P3 dengan dosis 720 mg serbuk daun kelor.

Dosis yang paling efektif untuk menurunkan perlemakan hati adalah dosis 3 yaitu $720 \mathrm{mg}$. Pada kelompok dengan dosis tersebut menunjukkan bahwa asupan pakan diet normal dan serbuk daun kelor sebanyak $51,71 \%$ sehingga serbuk daun kelor yang diasup oleh tikus sebanyak 372,31 $\mathrm{mg}$. Hal ini sesuai dosis minimal serbuk daun kelor untuk orang dewasa $357 \mathrm{mg}$ untuk tikus seberat $200 \mathrm{~g}$ dan $25 \mathrm{~g}$ untuk anak berusia 3 tahun dengan berat $14 \mathrm{~kg}(18,19)$.

Serbuk kelor merupakan sumber makanan yang mengandung, protein, vitamin, mineral yang tinggi yang tinggi pada makanan. Penambahan serbuk daun kelor yang juga mengandung 40 nutrien essensial pada diet harian, menyebabkan terjadinya recovery secara cepat pada defisiensi gizi (20). Zat gizi serbuk daun kelor yang dapat menyebabkan penurunan perlemakan hati pada KEP adalah asam amino, Vitamin C dan Vitamin E.

Defisiensi pada intake asam amino essensial terjadi pada kondisi KEP. Hal ini menyebabkan terjadinya gangguan sintesis apoprotein yakni protein spesifik yang menjadi salah satu komponen mayor pembentuk lipoprotein. Lipoprotein merupakan media pengangkut lemak. Salah satu jenis lipoprotein adalah VLDL yang terdiri dari apoprotein B-100, apoprotein C-1, apoprotein C-II, dan apoprotein C-III. Apoprotein tersebut mengangkut lemak berupa trigliserida dan kolesterol dari hati ke jaringan. Gangguan sintesis apoprotein dapat menghambat pembentukan lipoprotein, dan transportasi lemak dari hati ke jaringan. Hal ini menyebabkan akumulasi lemak di hati yang berlebihan yang dikenal dengan perlemakan hati (7). Dengan pemberian serbuk daun kelor yang mengandung asam amino yang tinggi kebutuhan asam amino dapat dipenuhi, sehingga pembentukan apoprotein yang ada pada VLDL dapat tercukupi untuk mengangkut lemak berupa trigliserida dan kolesterol dari hati ke jaringan .

Vitamin E yang berada di dalam lapisan fosfolipid berfungsi 
menjaga membran sel asam lemak jenuh ganda dan komponen membran sel lain dari oksidasi radikal bebas dengan memutus rantai peroksidasi lipid. Pemutusan rantai peroksidasi lipid dilakukan dengan cara menyumbangkan satu gugus $-\mathrm{OH}$ pada cincin radikal bebas sehingga terbentuk vitamin E yang stabil dan tidak merusak membran. Vitamin C merupakan antioksidan yang larut air yang bekerja pada sitosol secara ekstraseluler. Vitamin ini bereaksi dengan anion superoksid, radikal hidroksil dan lipid peroksida. Dengan kemampuan vitamin $\mathrm{C}$ sebagai penghambat radikal bebas, maka perananya sangat penting dalam menjaga integritas membran sel (21). Dengan mekanisme kerja yang berbeda, jika kedua vitamin ini digunakan dalam waktu yang sama diharapkan akan mendapat efek yang maksimal dalam menghadapi radikal bebas.

Vitamin C dan Vitamin E merupakan antioksidan, tetapi dapat berubah menjadi prooksidan jika ada dalam dosis tinggi. Vitamin E yang berlebihan akan mempropagasi reaksi pada membran sel sehingga membran tidak stabil terhadap peroksidasi lipid dan membentuk radikal bebas. Peningkatan radikal bebas mempengaruhi yang merupakan pembentuk VLDL. Hal ini menyebabkan sintesa VLDL menurun yang menyebabkan akumulasi lemak di hati. Kondisi ini yang menyebabkan pada pemberian daun kelor dosis $144 \mathrm{mg}$ mengalami kenaikan derajat perlemakan hati (7).

\section{Ekspresi IL-6}

Kelompok dengan diet KEP tanpa asupan daun kelor memiliki ekspresi IL-6 paling tinggi dengan rata-rata $52,12 \pm 1,59 \%$. Pada kondisi KEP terjadi glukoneogenesis, lipolisis dan pemecahan protein. Gliserol dan asam amino merupakan bahan yang oleh proses glukoneogenesis karena glukosa sudah tidak memadai lagi. Hal ini menyebabkan meningkatnya fosforilasi oksidasi yang menghasilkan radikal superoksida dan turunnya superoksida dismutase (SOD) sehingga meningkatkan radikal bebas (22). Peningkatan radikal bebas mengaktivasi makrofag sehingga terjadi aktivasi NFkB yang memproduksi sitokin proinflamasi (23).

Diet non protein pada kelompok $\mathrm{K}+$ menyebabkan

\section{DAFTAR PUSTAKA}

1. Onis M, Monteiro C, Akre J, and Lugstom C. The Worldwide Magnitude of Protein-Energy Malnutrition: An Overview from the WHO Global Database on Child Growth. Bulletin of the World Health Organization. 1993; 6: 703-712.

2. Bappenas RI. Rencana Aksi Nasional Pangan dan Gizi 2006-2010. Jakarta: Bappenas RI; 2006.

3. Koruk M, Taysi S, Savas MC, Yilmaz O, Akcay F, and Karakok M. Oxidative Stress and Enzymatic Antioxidant Status in Patients with Nonalkoholic Teatohepatitis. Annals of Clinical and Laboratory Science. 2004; 34(1): 57-62.

4. Departemen Kesehatan RI. Riskesdas Prevalensi Gizi Buruk 2007. Jakarta: Depepartemen Kesehatan RI; 2007.

5. Sediaoetama A. Ilmu Gizi; Untuk Mahasiswa dan berkurangnya asupan asam amino yang menyebabkan terjadinya perlemakan hati yang ditunjukkan pada penelitian ini. Lemak tak jenuh ganda di hati peka terhadap radikal bebas yang menyebabkan terbentuknya peroksida lipid. Peningkatan peroksida lipid ini merusak membran sel dan DNA yang mengarah pada apoptosis. Peningkatan progesivitas kerusakan hati mengakibatkan aktivasi Reactive Oxygen Species (ROS) (3).

Hasil penelitian juga menemukan efek daun kelor pada dosis 720 mg optimum untuk menurunkan ekspresi IL-6. Serbuk daun kelor dengan makronutrien dan mikronutrien tinggi dapat memenuhi kebutuhan protein dan vitamin pada tikus KEP dapat menurunkan perlemakan hati. Hal ini ditunjukkan gambar 4. Pemberian serbuk daun kelor yang kaya akan protein, diharapkan dapat memenuhi energi dan asam amino sehingga kebutuhan asam amino terpenuhi. Dengan tercukupinya asam amino maka pembentukan lipoprotein yang di dalamnya terdapat approtein B dan apoprotein C dapat terjaga sehingga proses pengeluaran lemak dari hati ke jaringan dapat mengimbangi masuknya lemak ke hati (7). Dengan berkurangnya perlemakan hati maka akan terjadi penurunan peroksida lipid dan radikal bebas sehingga terjadi penurunan IL-6 yang merupakan salah satu sitokin proinflamasi (7).

Pemberian daun kelor dosis $40 \mathrm{mg}$ menunjukkan peningkatan ekspresi IL-6. Hal ini disebabkan karena terlalu tinggi asupan vitamin $\mathrm{E}$ dan vitamin C. Vitamin C merupakan antioksidan yang dapat meningkatkan absorpsi Fe, tetapi jika terlalu banyak menumpuk di sel maka akan prooksidan dan meningkatkan radikal bebas. Di samping itu vitamin $E$ yang berlebihan akan mempropagasi reaksi pada membran sel sehingga membran tidak stabil terhadap peroksidasi lipid dan membentuk radikal bebas. Peningkatan radikal bebas ini mengaktivasi sitokin proinflamasi yang salah satunya adalah IL-6 (7). Pemberian serbuk daun kelor (Moringa oleifera) varietas NTT terbukti mampu menurunkan derajat perlemakan hati dan ekspresi IL-6 hati pada tikus dengan KEP.

Profesi. Jakarta: Dian Rakyat; 2004; hal. 27-33.

6. Aditiawarman. Pengaruh Perubahan Profil Asam Amino terhadap Peningkatan Profil Protein Endoplasmic Reticullum Stress (GRP78) dan Penurunan Kadar VEGF Plasenta pada Kehamilan dengan Hipoalbunemia. [Disertasi]. Universitas Airlangga, Surabaya. 2008.

7. Murray RK, Granner, Mayes, and Roodwel. Harpers Ilustrated Biochemistry. 26rd edition. New York: Mc Graw Hill Company; 2003; p. 205-218.

8. Baratawidjaja dan Iris K. Imunologi Dasar. Edisi 8. Jakarta: Balai Penerbit Fakultas Kedokteran Universitas Indonesia; 2009; hal. 93-104.

9. Dulger H, Arik M, Ramazan M, et al. Proinflammatory cytokines in Turkish Children with Protein-Energy Malnutrition. Journal of Health Science. 2002; 11(3): 363-365.

10. Fruhnbeck G, Ambrozi GJ, Muruzabal, JF, and Burrel 
MA. The Adipocyte: A Model for Integration of Endocrine and Metabolic Signalling in Energy Metabolism Regulation. American Journal of Physiology Endocrinology Metabolism. 2001; 280(6): 827-847.

11. Almatsier S. Prinsip Dasar Ilmu Gizi. Jakarta: Gramedia Pustaka Utama; 2001; hal. 54-70.

12. Amiglo KN. Moringa Oleifera An Underutilized Tree with Amazing Versatility. (Online) 2004. http://ebookbrowse.com/moringa-oleifera-anunderutilized-tree-with-amazing-versatility-pdfd63939156. [diakses 1 desember 2010].

13. Therik WD. Pemanfaatan Moringa Oleifera Lokal (Dalam Upaya Peningkatan Status Gizi Balita Anak Usia Sekolah dan Ibu Hamil. (Online) 2009. www.timorexpress.Com/index. [diakses 1 desember 2010].

14. Susanto H, Maslikah, Hernowati TE, and Therik WD. Efek Nutrisional Tepung Daun Kelor (Moringa oleifera) Varietas NTT Terhadap Kadar Albumin Tikus Wistar Kurang Energi Protein (Studi Invivo Kelor sebagai Kandidat Suplementasi pada Kasus Gizi Buruk). Publikasi IImiah Semnas MIPA Universitas Brawijaya. Malang, 27 Februari 2009.

15. Soresi M, Giannitrapani L, D'Antona F, et al. Interleukin-6 and Soluable Receptor in Patiens with Chirrosis and Hepatocelluler Carcinoma. World Journal of Gastroenterology. 2011; 12(16): 25632568.

16. Zhao L, Tang W, You Z, et al. Interleukin-17 Contributes to the Pathogenesis of Autoimmune Hepatitis through Inducing Hepaticlnterleukin-6 Expression. Plos One. 2011; 6 (4): 18909-18916.

17. Nurhayati. Reka Cipta Menu Balita dan Implementasinya dengan Pendekatan Holistik Sebagai Upaya Mengatasi Kesulitan Makan dan Kurang Gizi Pada Balita. Penelitian Hibah Bersaing. Fakultas Pendidikan Teknologi Dan Kejuruan Universitas Pendidikan Indonesia. 2008.

18. Fuglie LJ. The Miracle Tree: Moringa oleifera: Natural Nutrition for the Tropics. (Online) 1999. http://www.echotech.org/bookstore/advanced_sear ch_result.php?keywords=Miracle+Tree

19. Fuglie LJ. Combating Malnutrition with Moringa. Senegal: Bureau Regional Afrika; 2001.

20. Simbolon JM, Sitorus M, dan Kathrina N. Cegah Malnutrisi dengan Kelor. Yogyakarta: Penerbit Kanisius; 2008; hal. 7-17.

21. Hariyatmi. Kemampuan Vitamin E Sebagai Antioksidan terhadap Radikal Bebas pada Lanjut Usia. Universitas Muhammadiyah Surakarta Library. 2004; 14(1): 52-60.

22. Supariasa ID dan Bakri. Penilaian Status Gizi. Edisi ke 2. Jakarta: Penerbit Buku Kedokteran EGC; 2001; hal. 120-136.

23. Lampronti I, Khan MT, Bianchi N, et al. Bangladeshi Medicinal Plant Exract Inhibiting Molecular Interactions Between Nuclear Factors and Target DNA Sequences Mimicking NFKb Binding Sites. Medical Chemistry. 2005; 1(4): 327-333. 